\title{
Effects of vermicompost, vermi-tea and chemical fertilizer on morpho- physiological characteristics of tomato (Solanum lycopersicum) in Suleymanpasa District, Tekirdag of Turkey
}

\author{
Zubair Aslam ${ }^{1}$, Ali Ahmad ${ }^{1 *}$, Korkmaz BELLİTÜRK ${ }^{2}$, Naeem Iqbal ${ }^{3}$, \\ Muhammad Idrees ${ }^{3}$, Wajeeh Ur Rehman ${ }^{1}$, Ghulam Akbar ${ }^{4}$, Muhammad \\ Tariq ${ }^{5}$, Mohsin Raza ${ }^{4}$, Sania Riasat ${ }^{4}$ and Sami ur Rehman ${ }^{1}$ \\ 1. Department of Agronomy, University of Agriculture, Faisalabad, 38000-Pakistan \\ 2. Department of Soil Science and Plant Nutrition, Faculty of Agriculture, Tekirdag Namık Kemal University, \\ Suleymanpasa, Tekirdag-Turkey \\ 3. Agronomic Research Institute, Plant Physiology Section, Ayub Agricultural Research Institute (AARI), \\ Faisalabad-Pakistan \\ 4. Department of Biochemistry, University of Agriculture Faisalabad, 38000-Pakistan \\ 5. Department of Agronomy, Ghazi University, Dera Ghazi Khan-Pakistan \\ *Corresponding author's email: aliahmadsial2643@gmail.com \\ Citation \\ Zubair Aslam, Ali Ahmad, Korkmaz BELLİTÜRK, Naeem Iqbal, Muhammad Idrees, Wajeeh Ur Rehman, Ghulam \\ Akbar, Muhammad Tariq, Mohsin Raza, Sania Riasat and Sami ur Rehman. Effects of vermicompost, vermi-tea and \\ chemical fertilizer on morpho-physiological characteristics of tomato (Solanum lycopersicum) in Suleymanpasa \\ District, Tekirdag of Turkey. Pure and Applied Biology. Vol. 9, Issue 3, pp1920-1931. \\ http://dx.doi.org/10.19045/bspab.2020.90205
}

\begin{tabular}{llll}
\hline \hline Received: 16/01/2020 & Revised: 22/04/2020 & Accepted: 28/05/2020 & Online First: 29/05/2020 \\
\hline \hline
\end{tabular}

\section{Abstract}

Nutrients deficiency is a major threat to tomato growth. The effects of nutrients can be mitigated by vermicompost, vermi-tea and chemical fertilizers. To combat the nutrients deficiency, an experiment was conducted in Riverm Kompost Vermikompost Tarım Hay. Mak. San. ve Ltd. Şti. Suleymanpasa, Tekirdag, Turkey under field conditions. In field four different states of fertilizers [ $\mathrm{F}_{0}$ : Control (No fertilizer application); $\mathrm{F}_{\mathrm{vc}}$ : Solid vermicompost @ 6 ton/ha; Fvt: vermi-tea @ 5\%; Fc: Chemical fertilizers (N\&P) @ $140-120 \mathrm{~kg} / \mathrm{ha}$ were applied in tomato variety Kuzeyköy. The plants were harvested 45 days after sowing and the evaluation was done based on various morphological (leaf length, plant height, leaf breadth, number of leaf, days taken for flowering, primary branches per plant, stem diameter, fruit diameter, number of fruits per plant, petiole length, ) and physiological parameters (relative water contents (RWC), and membrane stability index (MSI)). The obtained results indicated that vermi-fertilizers and chemical fertilizer significantly increased all of the above-said parameters of tomato as compared to control but the foliar application of 5\% vermi-tea treatment showed maximum morphological and physiological performance of tomato.

Keywords: Morphological; Nutrients; Physiological; Tomato; Vermicompost 


\section{Introduction}

Tomato, a member of the Solanaceae family, is the most popular and important fruit crop used in the food industry due to its charming taste $[1,2]$. The use of tomato is worldwide in the form of fresh or processed tomato products like ketchup, paste and sauce [3]. It contains important compound lycopene which protects the oxidative damage of cells that is associated with harmful and uncontrolled cell proliferation referred as cancer [4]. The nutrients are necessary for the reproduction, increased growth and production of tomato crops. For this enhanced yield of tomato, the exact quantity of a specific nutrient at the right time is necessary [5].

Vermicompost is an organic compound synthesized by the action of microorganisms and earthworms on the waste organic substances. These organisms break down the organic material by transferring it into vermicompost that has good nutrition value for the crops. Therefore, the crops grow well and make better yield in the presence of vermicompost. It also improves soil porosity, retention of water contents and aeration capacity. Vermicompost contains phosphorus, nitrogen, magnesium, calcium and potassium which are required for microbial metabolic processes $[6,7]$. In this research work many experiments were performed in which the impact of vermicompost on different crops was expressed significant [8, 9]. Kovacik [10] performed experiments with the application of vermicompost and obtained better yield and quality with improved ripening stage.

Vermi-tea is rich in nutrients, minerals, enzymes dissolved organic nutrients and hormones [11]. With the addition of vermitea the crops quality, yield and plant vigor were improved $[12,13]$. It also improved the root length, shoot length, membrane stability and crop's growth [14].
In this technologically developed era, the use of chemical fertilizers with overdoses has become common for the high yield of crops. Along with higher production these fertilizers and pesticides have negative impact on human health and also decrease the soil nutrient efficiency and productivity. Therefore, chemical fertilizers alone cannot maintain long-range fertility so, these fertilizers can be applied with vermicompost formed by the combination of different waste organic raw material. This process is known as co-composting that was proved successful by the enhanced production of wheat crops applying animal manure, sludge's residues, sawdust and wood chips. This combination of chemical fertilizers and organic manure is becoming popular among the farmers due to awareness and improved production with the maintenance of soil fertility.

In another investigation, it has been observed that with the use of organic fertilizer rather than chemical fertilizer the soil $\mathrm{pH}$ and nutrient concentration were increased with higher microbial biomass. So, researchers preferred the use of organic substances for the improved crop production and nutrientrich soil maintenance for a long period of fertility conditions [15-17]. Arancon et al. [18] conducted an experiment to evaluate the effect of vermi-tea on growth and yield of tomato and lettuce in hydroponic environment. Vermi-tea increased the lettuce and tomato yield even at lower concentrations than the treatments without vermicompost tea. The presence of plant growth regulators such as auxins, gibberellins, cytokinin and humic acid in vermi-tea is responsible for increasing the yield of tomato and lettuce.

By increasing the importance of tomato and market availability of vermicompost, vermitea and other by-products of vermicomposting, it is distinctly essential to review its production in Tekirdag, Turkey. The production of tomato can be improved by 
studying locally produced organic fertilizers such as vermicompost and vermi-tea instead of using chemical fertilizer. The application of vermicompost as soil amendment increased the plant growth and yield, is well documented. However, the studies on its comparative analysis with chemical fertilizers and its foliar application are limited and need to be evaluated. Hence, the present experiment was conducted to investigate the comparative effect of organic fertilizer and synthetic fertilizer and to assess the morpho-physiological parameters of tomato.

\section{Materials and methods \\ Soil analysis}

The soil used for the experiment was clay loam. The soil analysis was done at Soil Science Laboratory No.1, Department of Soil Science and Plant Nutrition, Faculty of Agriculture, Tekirdag Namı Kemal University, Suleymanpasa, Tekirdag, Turkey and its data is given below in (Table 1).

Table 1. Analyzed clay loam soil parameters and their results

\begin{tabular}{|c|c|c|}
\hline Parameters & Results & Unit \\
\hline $\mathrm{pH}$ & 7.63 & $\%$ \\
\hline Salt & 0.06 & $\%$ \\
\hline Lime & 5.77 & $\%$ \\
\hline ISBA & 53.00 & $\%$ \\
\hline Organic matter & 1.46 & Ppm \\
\hline Total nitrogen $(\mathrm{N})$ & 0.07 & Ppm \\
\hline Phosphorus $(\mathrm{P})$ & 30.43 & Ppm \\
\hline Potassium $(\mathrm{K})$ & 235.19 & $\mathrm{Ppm}$ \\
\hline Calcium $(\mathrm{Ca})$ & 532.41 & $\mathrm{Ppm}$ \\
\hline Magnesium $(\mathrm{Mg})$ & 308.54 & Ppm \\
\hline Iron $(\mathrm{Fe})$ & 6.54 & Ppm \\
\hline Copper $(\mathrm{Cu})$ & 2.06 & Ppm \\
\hline Zinc $(\mathrm{Zn})$ & 3.36 & \\
\hline Manganese $(\mathrm{Mn})$ & 13.02 & \\
\hline
\end{tabular}

\section{Experimental set-up}

This research work was conducted in Riverm Kompost Vermikompost Tarım Hay. Mak. San. ve Ltd. Şti. Suleymanpasa, Tekirdag, Turkey under field conditions. The layout of experiment was designed in completely randomized design with three replicates in the season of Kharif. The following data about different aspects of tomato plants were collected. 1) Leaf length $(\mathrm{cm})$ of randomly selected three plants was measured with the help of scale meter and average was taken. 2) Plant height $(\mathrm{cm})$ was measured with the help of meter rod by selecting three plants randomly and average was computed. 3) Leaf breadth $(\mathrm{cm})$ was recorded with scale meter by taking average of randomly selected three plants. 4) The number of leaves was counted manually of randomly selected three plants and average was taken. 5) Days taken for flowering were counted by number of days taken to initiate flowers. 6) Primary branches per plant were recorded manually by computing average of randomly selected three plants. 7) Stem diameter (cm) was measured with the help of measuring tape of three plants and average was taken. 8) Fruit diameter $(\mathrm{cm})$ was recorded with the help of measuring tape of three plants and average was taken. 9)Number of fruits per plant were 
counted of three plants and average was computed. 10) Petiole length $(\mathrm{cm})$ was measured with a scale meter of randomly selected three plants and average was computed. 11) Membrane Stability Index (MSI) \% was measured according to the procedure [19] as mentioned, $0.1 \mathrm{~g}$ leaf samples were placed in distilled water in two sets. In one experiment, expose to $40^{\circ} \mathrm{C}$ for a half-hour to determine electrical conductivity $\left(\mathrm{C}_{1}\right)$ with the help of conductivity meter. While in other experiment expose to $100^{\circ} \mathrm{C}$ for one hour to determine electrical conductivity $\left(\mathrm{C}_{2}\right)$ with the help of conductivity meter. 12) The relative water contents of plant samples were measured by following the procedure of [20] using the formula (fresh weight - dry weight)/ (turgor weight - dry weight) $\times 100$.

\section{Statistical analysis}

The recorded data was statistically analyzed via Fisher's analysis of variance (ANOVA) technique. LSD test was used $(\mathrm{p} \leq 0.05)$ to compare significant treatments means using Statistic version 8.1(Analytical Software (C), 1985-2005) and according to [21].

\section{Results and discussion}

\section{Leaf length (cm)}

More leaf length is important for maximum photosynthates production. The analyzed data regarding leaf length showed that vermicompost, vermi-tea and chemical fertilizer had significant effects on leaf length. Maximum leaf length was observed where vermi-tea was foliar applied while minimum leaf length was observed where chemical fertilizers applied and moderate results were obtained where vermicompost applied. Similar findings had been observed in a research work on radish performed by [22]. in which maximum yield had been observed (Table 2, Fig. 1).

\section{Leaf breadth $(\mathbf{c m})$}

More leaf breadth is important for maximum photosynthates production. More breadth absorbed more sunlight for photosynthesis because leaf area was more. The analyzed data regarding leaf breadth showed that vermicompost, vermi-tea and chemical fertilizer had significant effects on leaf breadth. Maximum leaf breadth was observed where vermi-tea was foliar applied while minimum leaf breadth was observed where chemical fertilizers applied and moderate results were obtained where vermicompost applied. Similar findings had been observed in a research work [23]. in which maximum growth had been observed (Table 2, Fig. 1).

\section{Number of leaves}

Leaves are the major component of plants making and storing green pigment chlorophyll which involves in the synthesis of glucose by a process of photosynthesis. The number of leaves was counted for each crop growth by applying vermicompost, vermi-tea, and chemical fertilizer. The maximum number of leaves were produced by a crop plant treated with vermi-tea and minimum leaves were grown by control in which additional growth-enhancing component was not added. Vermicompost treated crop also made larger number of leaves after vermi-tea. The similar findings had been observed in a research work [24] in which the maximum number of leaves had been observed (Table 2, Fig. 1).

\section{Plant height (cm)}

Plant height is important for maximum yield of tomato because more height the plant bear more fruits because fruits are starting from first branch to end of the plant like canopy. The analyzed data regarding plant height showed that vermicompost, vermi-tea and chemical fertilizer had significant effects plant height. More plant height was observed where vermi-tea was foliar applied while less height was observed where chemical fertilizers applied, and moderate results were obtained where vermicompost applied (Table 2, Fig. 1). The similar findings had been observed in a research work on cotton 
performed by [25] in which maximum yield attributes had been observed. Morphological parameters of tomato plant were positively affected by application of macro and micronutrients by biofertilizers such as vermicompost. Thus, might increase the chlorophyll formation, photosynthetic activity, nitrogen metabolism and auxin contents in plant. The investigation agrees with the findings of $[26,27]$.

\section{Days for flowering}

Days for flowering are important for maximum yield of tomato because as an early flowering start then more time got by crop and increase the number of picking as it is an indeterminate crop. The analyzed data regarding days for flowering showed that vermicompost, vermi-tea and chemical fertilizer had significant effects on days for flowering. Less number of days for flowering was observed where vermi-tea was foliar applied while more days for flowering were observed where chemical fertilizers applied, and moderate results were obtained where vermicompost applied (Table 2, Fig. 1). The similar findings had been observed in a research work on cotton performed by [25] in which maximum yield attributes had been observed. Morphological parameters of tomato plant were positively affected by application of macro and micronutrients by biofertilizers such as vermicompost. Thus, might increase the chlorophyll formation, photosynthetic activity, nitrogen metabolism and auxin contents in plant. The investigation agrees with the findings of $[26,27]$.

\section{Primary branches per plant}

More primary branches important for maximum fruit-bearing. The analyzed data regarding primary branches per plant showed that vermicompost, vermi-tea and chemical fertilizer had significant effects on primary branches per plant. Maximum number of primary branches per plant was observed where vermitea was foliarly applied while minimum primary branches were observed where chemical fertilizers applied, and moderate results were obtained where vermicompost applied. The similar findings had been observed in a research work performed by [28] in which maximum monopodial and sympodial branches had been observed (Table 2, Fig. 1).

\section{Stem diameter $(\mathbf{c m})$}

More stem diameter is important for maximum plant vigor and prevent from lodging. The analyzed data regarding stem diameter showed that vermicompost, vermitea and chemical fertilizer had significant effects on stem diameter. Maximum stem diameter was observed where vermi-tea was foliar applied while minimum stem diameter was observed where chemical fertilizers applied and moderate results were obtained where vermicompost applied. The similar findings had been observed in a research work on tomato performed by [29]. in which maximum stem diameter had been observed (Table 2, Fig. 1).

\section{Fruit diameter (cm)}

More leaf length is important for bigger size of fruit and its maximum weight. The analyzed data regarding fruit diameter showed that vermicompost, vermi-tea and chemical fertilizer had significant effects on fruit diameter. Maximum fruit diameter was observed where vermi-tea was foliar applied while minimum fruit diameter was observed where chemical fertilizers applied and moderate results were obtained where vermicompost applied. The similar findings had been observed in a research work on radish performed by [30] in which maximum yield had been observed (Table 2, Fig. 1).

\section{Number of fruits per plant}

More fruits are important for the highest yield. The analyzed data regarding number of fruits per plant showed that vermicompost, vermi-tea and chemical fertilizer had significant effects on number of fruits per plant as compared to control. Maximum number of fruits per plant were observed 
where vermi-tea was foliar applied while minimum number of fruits per plant was observed where chemical fertilizers applied, and moderate results were obtained where vermicompost applied. The similar findings have been observed in a research work performed on tomato by [31], in which maximum number of fruits per plant had been observed (Table 2, Fig. 1). The vermi-tea contains total $\mathrm{N} 0.92 \%$, total $\mathrm{P}_{2} \mathrm{O}_{5} 0.74 \%$, and total $\mathrm{K}_{2} \mathrm{O} 0.85 \%$ [32]. Vermicompost tea is effective amendment for plant growth and yield and suppression of diseases and insect pests [33]. It contains vitamins, amino acids, nutrients such as nitrogen, potassium, calcium, magnesium, zinc, iron, copper and growth regulators such as auxin and cytokinin [34].

\section{Petiole length $(\mathrm{cm})$}

More petiole length and width are important for a healthy leaf that prevent the leaf from senescence and abscission. The analyzed data regarding petiole length showed that vermicompost, vermi-tea and chemical fertilizer had significant effects on petiole length. Maximum petiole length was observed where vermi-tea was foliar applied while minimum petiole length was observed where chemical fertilizers applied and moderate results were obtained where vermicompost applied. The similar findings had been observed in research work on vegetative growth of different crops performed by [35]. in which maximum growth attributes had been observed(Table 2, Fig. 1).

\section{Relative water contents}

The presence of water is important for the metabolic processes and photosynthesis. So, the efficient uptake of water by the roots has great importance. Here in this study the impact of vermicompost, vermi-tea and chemical fertilizer on the uptake of water have been studied where the effect of vermitea have been observed maximum for the uptake of relative water contents. The measurement of relative water contents was observed minimum in the crops without fertilizer. The similar findings have been observed in a research work on radish performed by [36] in which maximum yield and relative water contents have been observed. In another study where increased relative water contents enhanced the production and reduced water contents decreased the yield (Table 2, Fig. 1) [37].

\section{Membrane stability index}

Nutrients stress condition restricts the plants growth and minimizes the production by changing plant's morpho-physiological processes which affect membrane stability. In this research work the impact of different fertilizers on membrane stability index has been observed in which maximum membrane stability index was made by crop treated with vermi-tea. Chemical fertilizers and vermi-tea applied crops also have good membrane stability index while minimum membrane stability index was observed (Table 2, Fig. 1) by a crop without any fertilizer treated [38]. 
Table 2. Mean sum of square of morpho-physiological parameters as influenced by different organic and inorganic amendments in tomato

\begin{tabular}{|c|c|c|c|c|c|c|c|c|c|c|c|c|}
\hline $\begin{array}{c}\text { Mean sum } \\
\text { of square }\end{array}$ & $\begin{array}{c}\text { Leaf } \\
\text { length } \\
(\mathrm{cm})\end{array}$ & $\begin{array}{c}\text { Plant } \\
\text { height } \\
(\mathbf{c m})\end{array}$ & $\begin{array}{c}\text { Leaf } \\
\text { breadth } \\
(\mathrm{cm})\end{array}$ & $\begin{array}{l}\text { Number } \\
\text { of leaf }\end{array}$ & $\begin{array}{l}\text { Days for } \\
\text { flowering }\end{array}$ & $\begin{array}{c}\text { Primary } \\
\text { branches } \\
\text { per } \\
\text { plant } \\
\end{array}$ & $\begin{array}{c}\text { Stem } \\
\text { diameter } \\
(\mathbf{c m})\end{array}$ & $\begin{array}{c}\text { Fruit } \\
\text { diameter } \\
(\mathbf{c m})\end{array}$ & $\begin{array}{c}\text { Number } \\
\text { of fruits } \\
\text { per } \\
\text { plant }\end{array}$ & $\begin{array}{l}\text { Petiole } \\
\text { length } \\
(\mathrm{cm})\end{array}$ & $\begin{array}{c}\text { Relative } \\
\text { water } \\
\text { contents } \\
(\%) \\
\end{array}$ & $\begin{array}{c}\text { Membrane } \\
\text { stability } \\
\text { index }(\%)\end{array}$ \\
\hline Replication & 0.12 & 16.33 & 1.82 & 9.00 & 0.33 & 1.58 & 0.19 & 0.64 & 1.75 & 0.01 & 6.58 & 9.08 \\
\hline Treatment & $3.05 * *$ & $572.52 * *$ & $0.08 * *$ & $227.77 * *$ & $146.33 * *$ & $135.86^{* *}$ & $2.47 * *$ & $29.98 * *$ & $128.55 * *$ & $0.45^{* *}$ & $45.00 * *$ & $104.52 * *$ \\
\hline Error & 0.04 & 18.11 & 0.10 & 7.77 & 1.66 & 8.36 & 0.06 & 0.67 & 1.30 & 0.04 & 2.58 & 1.19 \\
\hline
\end{tabular}


Aslam et al.

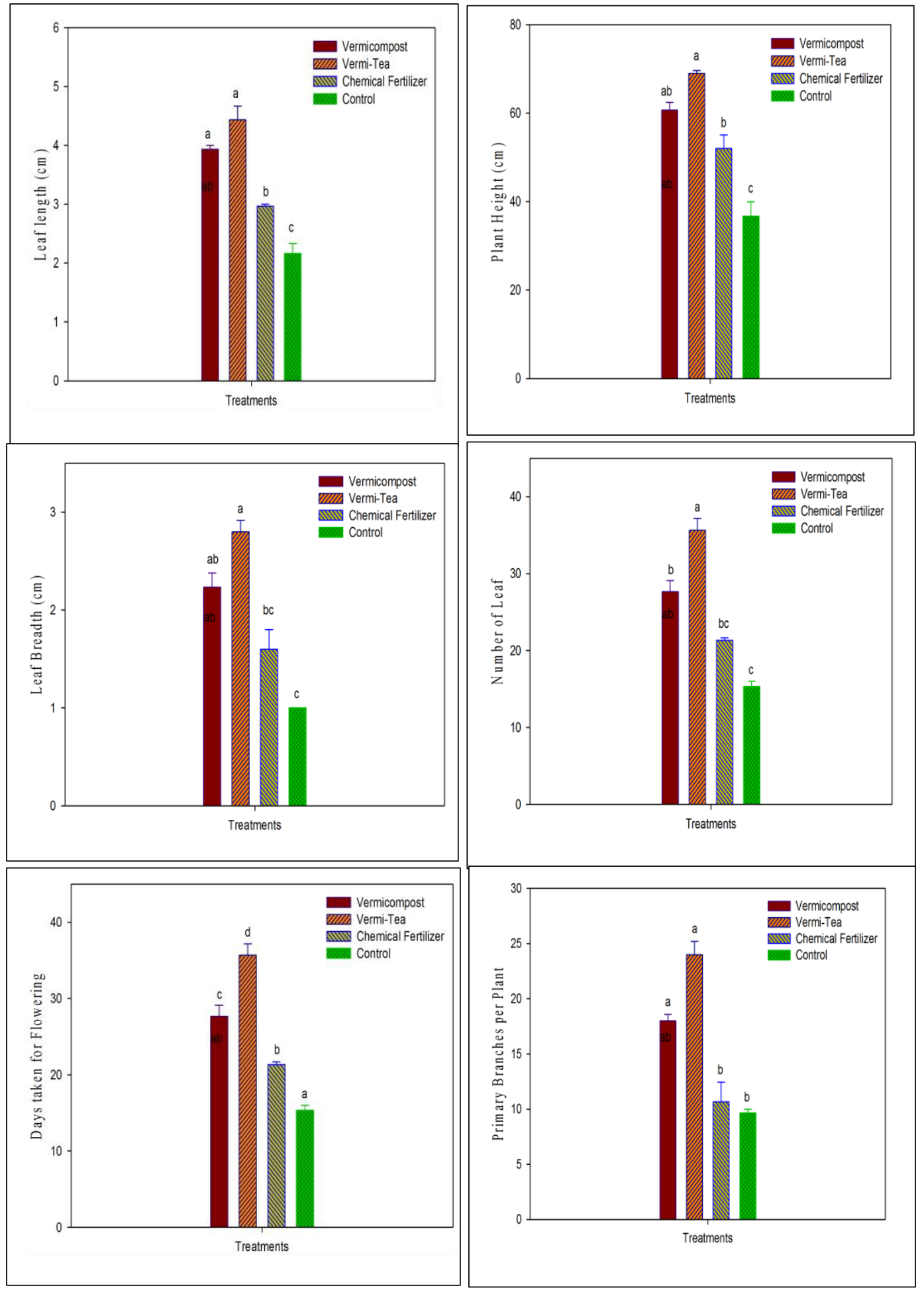



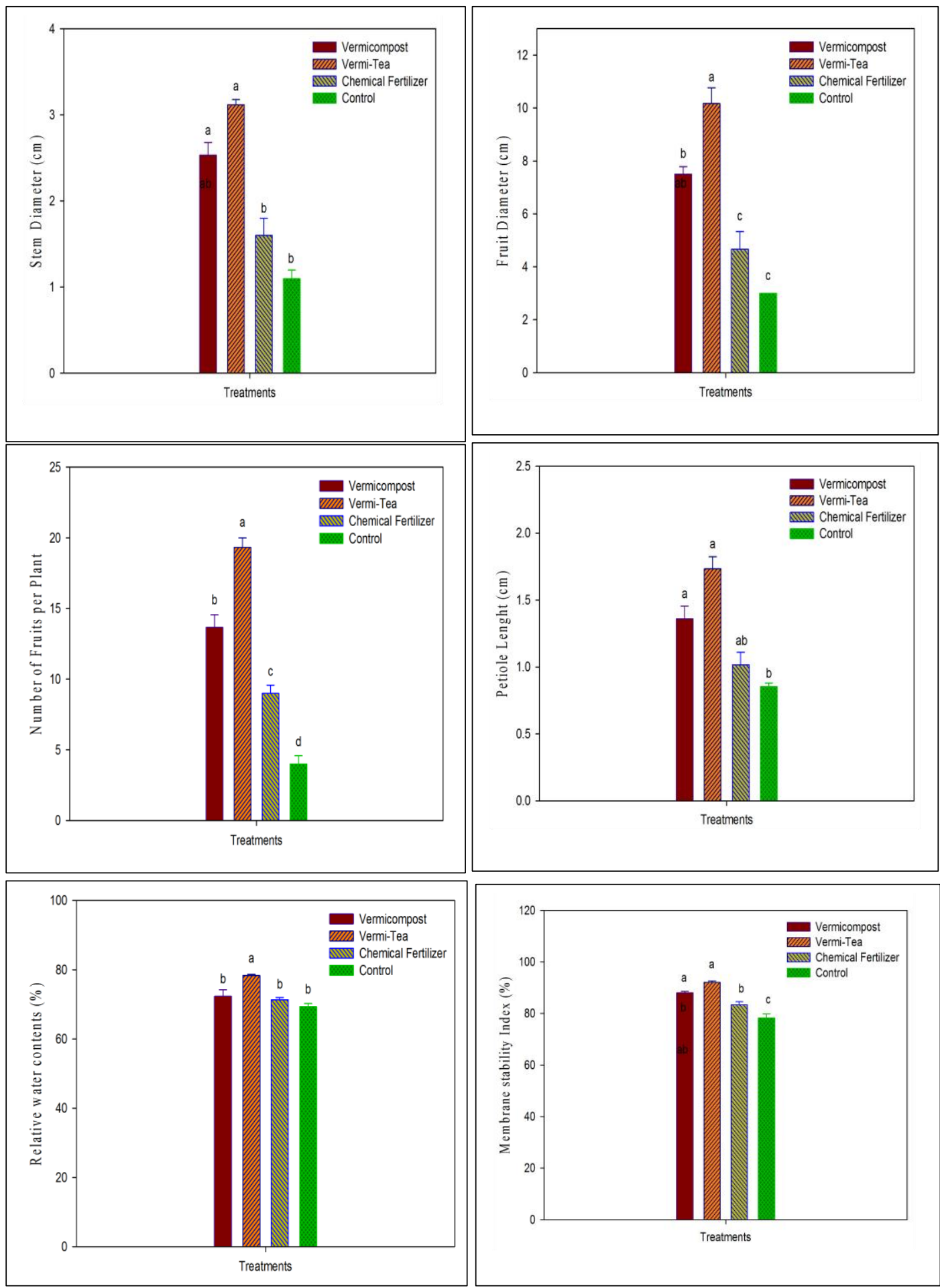

Figure (1a, b, c, d, e, f, g, h, I, j, k, l). Effects of vermicompost, vermi-tea and chemical fertilizer on morpho-physiological characteristics of tomato 


\section{Conclusion}

Vermi-fertilizers and chemical fertilizer significantly increased all the above said parameters of tomato excluding days for flowering as compared to control but foliar application of 5\% vermi-tea treatment showed maximum morphological and physiological performance of tomato. So, it is recommended the use of vermi-tea to the farmers for better crop production.

Authors' contributions

Conceived and designed the experiment: A Ahmad, Z Aslam \& K BELLITÜ̈RK, Performed the experiment: A Ahmad, Z Aslam \& K BELLITÜ̈RK, Analyzed the data: A Ahmad, Z Aslam \& K BELLITÜ̈RK, Contributed reagents/ materials/ analysis tools: Z Aslam, K BELLİTÜRK \& A Ahmad, Wrote the paper: Z Aslam, A Ahmad, K BELLITÜRK, $\mathrm{N}$ Iqbal, $\mathrm{M}$ Idrees, WU Rehman, G Akbar, M Tariq, M Raza, S Riasat \& SU Rehman.

\section{Acknowledgement}

The authors gratefully acknowledge HEC for providing financial support to carry out this research work under HEC projects ["Vermicomposting: An Agricultural Waste Management Technology", Pak-Turk Researchers Mobility Grant Program PhaseII, vide letter No. (Ph- II-MG-9)/ PAKTURK/R\&D/HEC/2018 and NRPU-HEC project no. 7527/Punjab/NRPU/R\&D/HEC/2017 Vermicomposting: A resourceful organic fertilizer to improve agriculture production and soil health].

\section{References}

1. Jenkins JA (1948). The origin of the cultivated tomato. Econ Bot 2: 379-392

2. Peralta IE, Spooner DM \& Knapp S (2008). Taxonomy of wild tomatoes and their relatives (Solanum sect. Lycopersicoides, sect. Juglandifolia, sect. Lycopersicon; Solanaceae). Am Soc Plant Taxon 151-160.
3. Nowicki M, Kozik EU \& Foolad MR (2013). Late blight of tomato. In: Varshney, R., Tuberosa, R. (Eds.), Translational Genomics for Crop Breeding. John Wiley \& Sons Ltd., New York, pp 241-265.

4. Giovannucci EA, Ascherio EB, Rimm MJ, Stampfer GA, Golditz GA \& Willet WC (1995). Intake of carotenoids and retinol in relation to risk of prostate cancer. J Natl Cancer Inst 87: 17671776.

5. Adekiya \& Ojeniyi (2002). Evaluation of tomato growth and soil properties under methods of seedling bed preparation in an Alfisol in the rainforest zone of southwest Nigeria. Soil Tillage Res 64: 275-279.

6. Vermi C (2001). Vermicomposting technology for waste management and agriculture: an executive summary. PO Box 2334, Grants Pass, OR 97528, USA: Vermi Co.

7. Bansal K \& Kapoor K (2000). Vermicomposting of crop residues and cattle dung with Eisenia foetida. Bioresour Technol 73(2): 95-98.

8. Lazcano C, Sampedro L, Zas R \& Domínguez J (2010). Vermicompost enhances germination of the maritime pine (Pinus pinaster Ait.). New Forests 3: 387-400.

9. Tejada M \& Benítez C (2011). Organic amendment based on vermicompost and compost: differences on soil properties and maize yield. Waste Manag Res 29(11): 1185-1196.

10. Kovacik P (2014). Principles and methods of plant nutrition. Nitra: SPU $v$ Nitre 191 pp (in Slovak).

11. Shivsubramanian K \& Ganeshkumar M (2004). Influence of vermiwash on biological productivity of Marigold. Madras Agric J 91(4): 221225. 
12. Shoji S (2005). Innovative use of controlled availability fertilizers with high performance for intensive agriculture and environmental conservation. Sci China Life Sci 48: 912920.

13. Pant D \& Adholeya A (2009). Concentration of fungal ligninolytic enzymes by ultrafiltration and their use in distillery effluent decolorization. World J Microb Biot 25(10): 1793-1800.

14. Siddiqui Y, Sariah M \& Razi I (2008). Trichoderma-fortified compost extracts for the control of Choanephora wet rot in okra production. Crop Prot 27: 385390.

15. Rahman AA, Jafarpour M, Kazemi E \& Pessarakli M (2017). Effect of raw materials on vermicompost qualities. J plant nutr 40(11): 1635-1643.

16. Singh J (1997). Habitat preferences of selected Indian earthworm species and their efficiency in reduction of organic material. Soil Biol Biochem 29: 585-588.

17. Reganold JP (1988). Comparison of soil properties as influenced by organic and conventional farming systems. Am J Alternative Agric 3: 144-155.

18. Arancon NQ, Owens JD \& Converse C (2019). The effects of vermicompost tea on the growth and yield of lettuce and tomato in a non-circulating hydroponics system. J Plant Nutr 42: 2447-2458.

19. Lee J (2010). Effect of application methods of organic fertilizer on growth, soil chemical properties and microbial densities in organic bulb onion production. Sci Hort 124: 299-305.

20. Premachandra GS, Saneoka H \& Ogata S (1990). Cell membrane stability an indicator of drought tolerance as affected by applied nitrogen in soybean. J Agric Sci (Camb) 115: 63-66.

21. Barrs, HD \& Weatherley PE (1962). A re-examination of the relative turgid technique for estimating water deficit in leaves. Aust J Biol Sci 15: 413-428.

22. Steel RGD Torrie JH \& Dickey D (1997). Principles and procedures of statistics: A Biometrical Approach. 3rd Ed. McGraw Hill Book Co, New York.

23. Meghvansi MK, Khan MH, Gupta R, Gogoi HK \& Singh L (2012). Vegetative and yield attributes of okra and naga chilli as affected by foliar sprays of vermiwash on acidic soil. J Crop Improvement 1(4): 520-531.

24. Balasubramanian AV, Nirmala, TD \& Merlin, FF (2009). Use of animal products in traditional agriculture. Chennai: Centre for Indian Knowledge Systems.

25. Ansari AA \& Sukhraj K (2010). Effect of vermiwash and vermicompost on soil parameters and productivity of okra (Abelmoschus esculentus) in Guyana. Afr J Agric Res 5(14): 1794-1798.

26. Musa SI, Njoku LK \& Ndiribe CC (2018). The Effect of Vermi Tea on the Growth Parameters of Spinacia oleracea L. (Spinach).

27. Naidu AK, Kushwah SS, MehtaAK \& Jain PK (2002). Study of organic, inorganic and biofertilizers in relation to growth and yield of tomato. JNKVV Res J Publ 35(1/2): 36-37.

28. ParmarU, Tembhre D, Das MP \& Pradhan J (2019). Effect of integrated nutrient management on growth development and yield traits of tomato (Solanum lycopersicon L.). $J$ Pharmacogn Phytochem 8(3): 27642768.

29. Bokhtiar SM \& Sakurai K (2005). Effects of organic manure and chemical fertilizer on soil fertility and productivity of plant and ratoon crops of sugarcane. Arch Agron Soil Sci 51: 325-334.

30. Domínguez JJ \& Edwards CA (2011). Biology and ecology of earthworms species used for vermicomposting. In: 
Edwards CA, Arancon NQ, Sherman RL (eds) Vermiculture technology: earthworms, organic waste and environmental management. Boca Raton: CRC Press. pp 27-40

31. Bansal K \& Kapoor K (2000). Vermicomposting of crop residues and cattle dung with Eisenia foetida. Bioresour Technol 73(2): 95-98.

32. Alcantara CG \& Gonzaga NR (2019). Nutrient uptake and yield of tomato (Solanum lycopersicum) in response to vermicast and vermi-foliar application. Org Agric 1-7.

33. Arancon, NQ, Pant A, Radovich $\mathrm{T}$, Nguyen VH, Potter J \& Converse C (2012). Seed germination and seed-ling growth of lettuce and tomato as affected by vermicompost water extracts (teas). Hort Sci 47(12): 1722-8.
34. Sinha RK, Agarwal S, Chauhan K \& Valani D (2010). The wonders of earthworms and its vermicompost in farm production: Charles Darwin's friends of farmers', with potential to replace destructive chemical fertilizers from agriculture. Agric Sci 1: 76-94.

35. Ansari A \& Sukhraj K (2010). Effect of vermiwash and vermicompost on soil parameters and productivity of okra in Guyana. Afr J Agr Res 14: 1794-1798.

36. Milind P \& Isha D (2013). Zea mays: A modern craze. Int Res Pharm 4: 39-43.

37. Mehta DC \& Dias FF (1999). Maize: Perspectives and applications in India. Starch - Stärke 51: 52-57.

38. Nuss ET \& Tanumihardjo SA (2010). Maize: a paramount staple crop in the context of global nutrition. Compr Rev Food Sci Food Saf 9: 417-436. 